\title{
Effect of Bagasse ash and Lime on the Compaction and Strength Properties of Black Cotton Soil
}

\author{
Md. Atir Azeem ${ }^{1}$, Saurabh Singh ${ }^{2}$, S S Divya ${ }^{3}$, Shahnawaz Ahmed Mir ${ }^{4}$ \\ ${ }^{1}$ M.Tech Scholar, Department of Civil Engineering, Suresh Gyan Vihar University Jaipur Rajasthan \\ ${ }^{2,3,4}$ Assistant Professor, Department of Civil Engineering, Suresh Gyan Vihar University Jaipur Rajasthan
}

\begin{abstract}
Bagasse ash is an industrial agro-waste abundantly available by-product in the sugarcane industry after combustion of bagasse. Sugar industries are facing severe environmental problems due to the lack of sustainable solutions for their waste management. Bagasse ash is effectively utilized for geotechnical applications due to the presence of reactive silica. The predominant reactive silica content in Bagasse ash, but insufficient lime content improves strength of black cotton soil with addition of lime. In the present study Bagasse ash and Lime is utilized to improve the compaction and strength behavior of highly expansive soil [known as black cotton (BC) soil] from India. Bagasse ash is added in different proportions by weight $(5,10,15,20,25$ and $30 \%)$ and Lime is added in different proportion by weight $(1,2,3,4,5$ and $6 \%)$ to the black cotton soil. Laboratory tests involved determination of compaction characteristics and strength properties. It is found that $15 \%$ Bagasse ash and $4 \%$ lime content is the optimum quantity to improve the compaction and strength properties of $\mathrm{BC}$ soil. The test results show that, with the addition of Bagasse ash and Lime to $B C$ soil, the maximum dry unit weight decreases with increase in optimum moisture content (OMC), which can be mainly attributed to the improvement in gradation of the soil. It is also observed that with addition of bagasse ash and Lime to $\mathrm{BC}$ soil there is significant improvement in strength which is attributed due to the pozzolanic reaction.
\end{abstract}

Keywords: Black cotton soil, Bagasse ash, Lime

\section{INTRODUCTION:}

Use of Agro- industrial waste to stabilize the Black cotton soils is gaining lots of importance in Geotechnical Engineering field, to overcome the disposal problem of these wastes which cause serious threat to the balance of environment and ecology. Bagasse is the fibrous by-product from sugar industries. When Bagasse is burnt, the resulting ash is bagasse ash. Bagasse ash is rich in reactive silica and Bagasse ash can be used as pozzolanic materil [1]. Many researchers reported the utilization of Bagasse ash to improve the engineering properties of Black cotton soil and reported that Index properties of Black cotton soil improved, UCS strength increased with addition of Bagasse ash [1], [2] and [3]. When the construction site is wet and unstable then Bagasse ash effectively dries wet soils and provides an initial rapid strength gain. [4]. The CBR value of weak sub-grade soils improved with addition of Bagasse ash [6, 7]. Bagasse ash is rich in reactive silica and low Lime content necessitates the use of Lime to enhance the pozzolanic rection. With addition of lime there is water absorption. Cation exchange, agglomeration occurs in the first stage of lime addition, which makes the wet soil dry and more workable and with curing period pozzolanic reaction is the main factor which imparts strength to soils. [8], [9]. Many researchers reported the improvement in compaction and strength properties with addition of lime to mixture of Black cotton soil and other additives such as mine tailings, flyash, [10], [11].

Construction activities on black cotton soil are challenging owing to the swell shrink behaviour with changes in moisture content causes detrimental effect to the structures. [12], [13]. Strength of Black cotton soil is reduced by swelling and shrinkage behaviour due to the particle re-arrangement and bond breakage according to [14],[15]. Construction of roads, retaining structures, embankments requires borrow soil and the cases where Black cotton soil cannot be avoided and need for soil stabilization becomes inevitable, and then improving the engineering properties of deficient soils with locally available industrial waste becomes need for study. Hence the main objective of the study is to improve the compaction and strength properties of Black cotton soils with industrial waste product Bagasse ash which in the presence of Lime

\section{MATERIALS AND METHODS \\ Materials \\ Black cotton soil}

In the present investigation black cotton soil is procured Sriganganagar, Kota, Rajasthan India by an open excavation at a depth of $1.5 \mathrm{~m}$ below the ground level. The soil is air dried, pulverized and sieved through $4.75 \mathrm{~mm}$ BIS sieve. Soil is classified as $\mathrm{CH}$ according to Indian Standard Soil Classification system. Grain size distribution and Plasticity chart are presented in Fig.1 and Fig. 2 respectively.

\section{Bagasse Ash}

Bagasse ash is collected from Ganganagar sugar mills Ltd, sri Ganganagar, Rajasthan, India. The organic content of bagasse ash is removed by burning in oil-fired furnace in Technomet Solutions, Peenya industrial area at a temperature of 600 degree Centigrade for 3 hours. Physical properties of bagasse ash and soil are presented in Table1.Chemical composition Bagasse ash is presented in Table 2. Grain size distribution of Bagasse ash is presented in Fig.1

Lime

Laboratory reagent hydrated lime $\left(\mathrm{Ca}[\mathrm{OH}]_{2}\right)$ supplied by Durga lime Industries, Daijar, Rajasthan has been used for experimental purpose. 
Table 1 Physical properties of soil and bagasse ash

\begin{tabular}{ccc}
\hline Property & Soil & Bagasse ash \\
\hline Specific gravity & 2.65 & 1.71 \\
Sand $(4.75-0.075 \mathrm{~mm})(\%)$ & 4 & 77.2 \\
Silt $(0.075-0.002 \mathrm{~mm})(\%)$ & 36 & -- \\
Clay (10.002 mm) (\%) & 60 & -- \\
Liquid limit (\%) & 91 & 61 \\
Plastic limit (\%) & 39 & Non plastic \\
Plasticity index (\%) & 52 & -- \\
Shrinkage limit (\%) & 11 & -- \\
Optimum moisture content (\%) & 32 & 43 \\
Max. dry unit weight $(\mathrm{kN} / \mathrm{m} 3)$ & 12.95 & 10.34 \\
\hline
\end{tabular}

Table 2Chemical composition of Bagasse ash

\begin{tabular}{ll}
\hline Chemical compound & Percentage \\
\hline Silica $\left(\mathrm{SiO}_{2}\right)$ & 65.92 \\
Alumina $\left(\mathrm{Al}_{2} \mathrm{O}_{3}\right)$ & 11.96 \\
Ferric oxide $\left(\mathrm{Fe}_{2} \mathrm{O}_{3}\right)$ & 2.86 \\
Calcium oxide $(\mathrm{CaO})$ & 5.6 \\
Magnesium oxide $(\mathrm{MgO})$ & 4.03 \\
Sodium oxide $\left(\mathrm{Na}_{2} \mathrm{O}\right)$ & 1.79 \\
Potassium oxide $\left(\mathrm{K}_{2} \mathrm{O}\right)$ & 3.19 \\
Loss on ignition & 16.18 \\
\hline
\end{tabular}

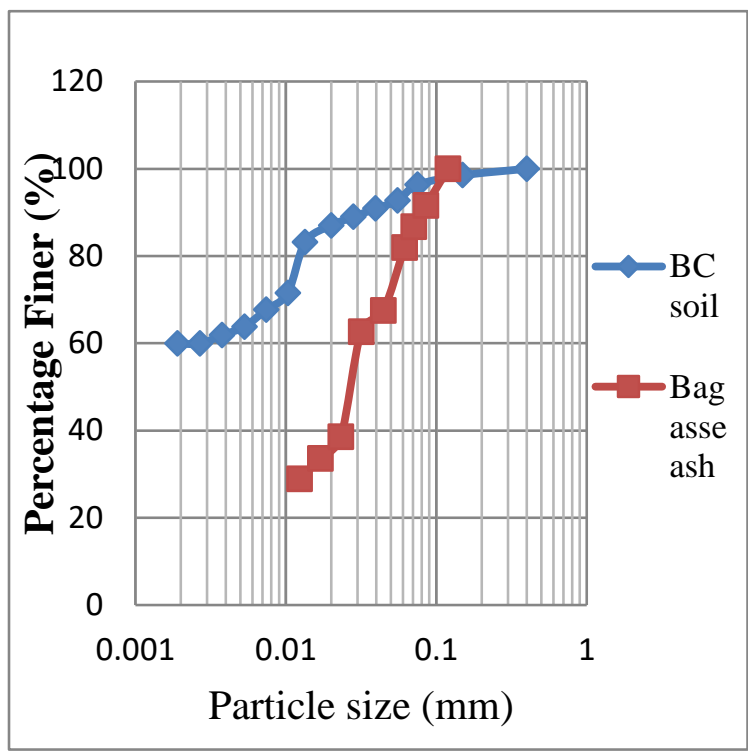

Fig. 1 Grain size distribution curve for BC soil

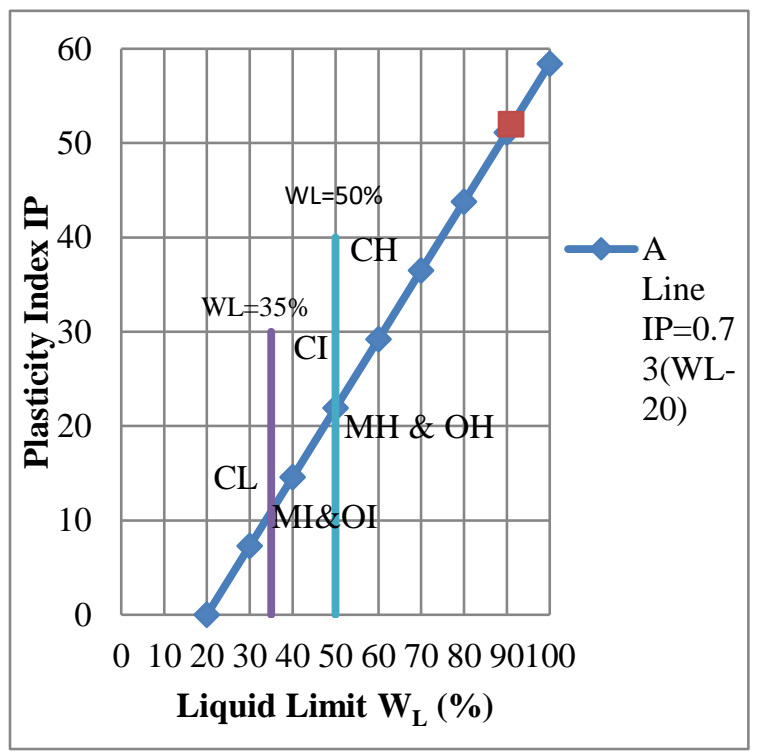

Fig. 2 Plasticity chart for $\mathrm{BC}$ soil 


\section{METHODOLOGY ADOPTED:}

Black cotton soil is mixed with varying percentage Bagasse ash (5\% to $30 \%)$ in an increment of $5 \%$ and Lime is added to soil and optimum percentage of Bagasse ash mixture $(1 \%$ to $6 \%$ ) in an increment of $1 \%$ on a dry weight basis. Mini compaction test procedure developed by Sridharan and Sivapullaiah (2005) is adopted to determine the compaction characteristics of soil. UCS tests were conducted according to IS 2720 (Part 10) under a constant strain rate of $1.25 \mathrm{~mm} /$ minute. Unconfined compressive strength tests are conducted for immediate as well as for 7 , 30, 45 and 60 and 90 days of curing periods. The samples prepared for UCS tests were placed in Zip lock polythene covers in an air tight desiccators and cured for $0.7,15,30,45,60$ and 90 days.

\section{RESULTS AND DISCUSSION \\ Effect of Bagasse ash on the compaction characteristics of black cotton soil}

Compaction increases the dry density of soil, thus increasing its shear strength and bearing capacity through an increase in frictional characteristics and brings about low permeability in soils. Compaction decreases the tendency for settlement of soil. Effect of Bagasse ash on the compaction characteristics of black cotton soil is presented in Table 3.The MDU of soil alone is $12.95 \mathrm{kN} / \mathrm{m}^{3}$ and $\mathrm{OMC}$ is $32 \%$. The MDU of Bagasse ash is $10.34 \mathrm{kN} / \mathrm{m}^{3}$ and OMC is $43 \%$. With addition of Bagasse ash. in an increment of $5 \%$ the MDU decreased and OMC increased this may be due to the low specific gravity value of 1.7 of the bagasse ash compared to that of the soil which is 2.65. [16] and also may be due to flocculation and agglomeration of clay-sized particles due to cat-ion exchange causes increase in volume and decrease in dry density. [17] With increase in bagasse ash content the OMC increased and this may be due to the increase in fines content with addition of bagasse ash with larger surface area that required more water to react. It could also be due to the morer amounts of water required for the hydration of the Bagasse ash. [18]

Table 3 Compaction characteristics of black cotton soil treated with various percentages of bagasse ash

\begin{tabular}{ccc}
\hline Mixture & MDU $\left(\mathbf{k N} / \mathbf{m}^{\mathbf{3}}\right)$ & OMC $(\boldsymbol{\%})$ \\
\hline Soil alone & 12.95 & 32.0 \\
BA alone & 10.34 & 43.0 \\
Soil + 5\% BA & 12.95 & 32.0 \\
Soil + 10\% BA & 12.85 & 33.0 \\
Soil + 15\% BA & 12.75 & 33.0 \\
Soil + 20\% BA & 12.55 & 34.0 \\
Soil + 25\% BA & 12.36 & 35.0 \\
Soil + 30\% BA & 11.96 & 36.0 \\
\hline
\end{tabular}

\section{Effect of Lime on the compaction characteristics of black cotton soil and Bagasse ash mixture}

Effect of Lime on the compaction characteristics is presented in Table4. With addition of lime further reduction in dry density is observed. The gradual reduction in maximum dry unit weight with the increase in lime content reflects enhanced flocculation and cementation of particles. The cat-ion exchange plays very important role in reducing dry density. With addition of lime, Calcium ions in lime replaces Sodium ions in soil which results in decrease in thickness of diffuse double layer.[17] Increasing tendency of optimum moisture content may be the cause of enhancement in water-holding capacity within flocs, which can accommodate water molecules. The increase in OMC is observed with addition of lime this may be due to increase in Hydroxyl ion concentration, liberated by addition of lime, increases the affinity of the surfaces of clay particles for water [19].

Table 3 Compaction characteristics of black cotton soil and Bagasse ash treated with various percentages of Lime

\begin{tabular}{ccl}
\hline Mixture & MDU $\left(\mathbf{k N} / \mathbf{m}^{3}\right)$ & OMC $(\%)$ \\
\hline Soil alone & 12.95 & 32.0 \\
Soil + 15\% BA & 12.75 & 33.0 \\
Soil + 15\% BA + 1\%L & 12.65 & 33.0 \\
Soil + 15\% BA + 2\%L & 12.65 & 34.0 \\
Soil + 15\% BA + 3\%L & 12.55 & 34.0 \\
Soil + 15\% BA + 4\%L & 12.45 & 35.0 \\
Soil + 15\% BA + 5\%L & 12.36 & 36.0 \\
Soil + 15\% BA + 6\%L & 12.36 & 36.0 \\
\hline
\end{tabular}

\section{Effect of bagasse ash on the strength properties of black cotton soil}

The optimum dosage of bagasse ash is found out by UCS test. UCS tests were conducted at 0 and 7 days of curing period for the samples prepared by mixing Black cotton soils with varying percentage of Bagasse ash. (5\% to $30 \%$ ). The results are represented in Fig.3. UCS strength of black cotton soil alone is $180 \mathrm{kPa}$. With addition of Bagasse ash up-to $15 \%$ the strength improved to $210 \mathrm{kPa}$ at 0 days curing period. Similar trend is observed at 7 days curing period. This may be due to flocculation of soil particles brought about by addition of bagasse ash. Beyond $15 \%$ addition of Bagasse ash the UCS strength decreased this may be due to the annoyance of clay matrix with increase in Bagasse ash and making the soil less clayey. [18].Also may be due to increase in diffuse double layer thickness and weaker bonds [20]. 


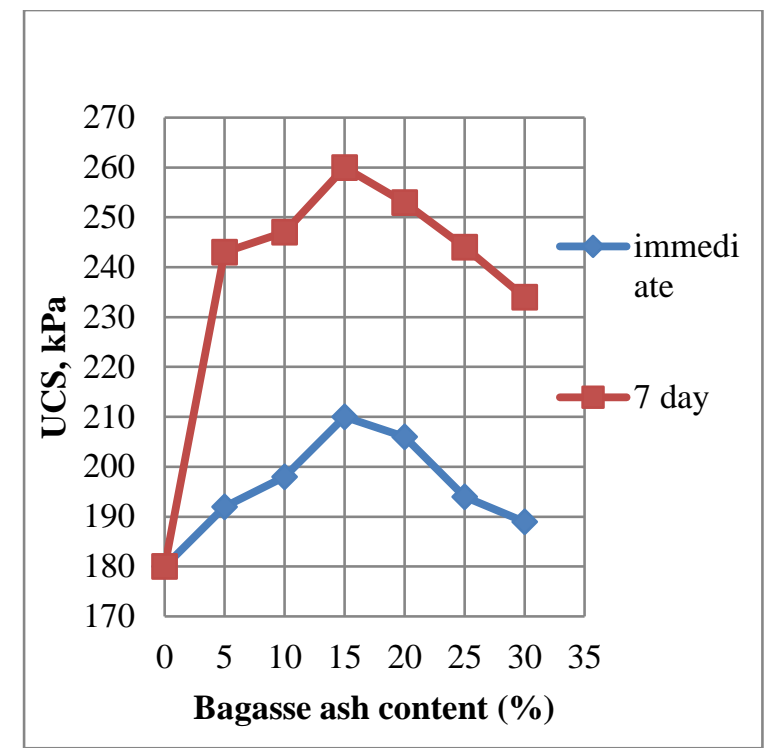

Fig.4 Variation of UCS strength with varying Bagasse ash Percentage

\section{Effect of Lime on the strength properties of black cotton} soil treated with Bagasse ash

Effect of Lime on the strength properties of black cotton soil treated with Bagasse ash is represented in Fig5It is observed that with addition of bagasse ash the strength improvement is not significant, hence lime is added to soil and Bagasse ash mixture. With increase in Lime up-to 4\%, increase in strength of 4 folds and 7 folds is observed at 0 days as well as 7 days curing period respectively.This may be due to the pozzolanic reaction as silica and alumina present in clay react with calcium from lime to form cementitious products like calcium-silicate-hydrates $(\mathrm{CSH})$ and calcium-aluminate- hydrates $(\mathrm{CAH})$. Beyond $4 \%$ addition of lime there is decrease in strength is observed on immediate testing and this may be due to non availability of Alumina and silica in the clay for pozzolanic reaction. Hence $4 \%$ Lime is chosen as the optimum dosage. [21]

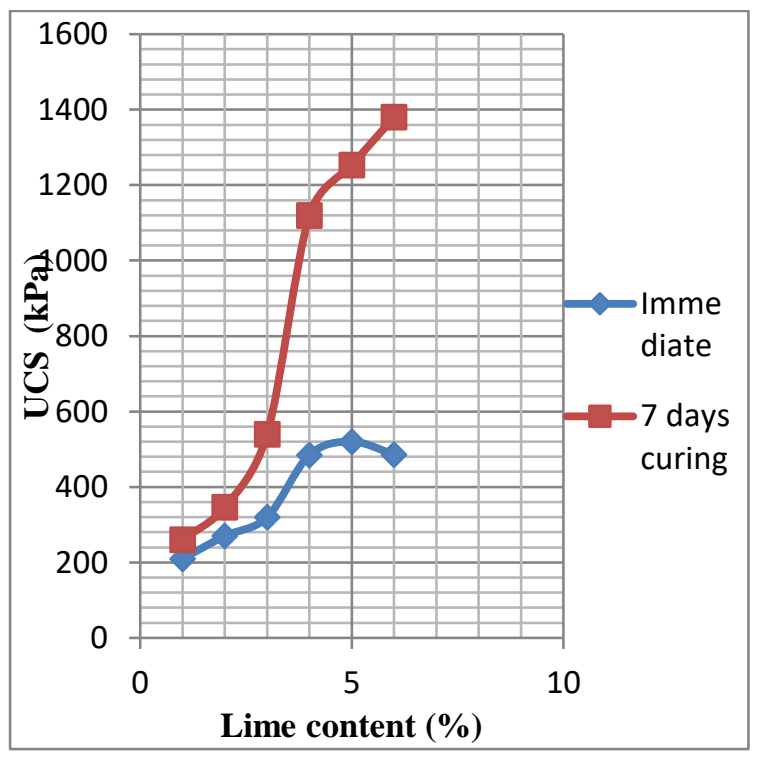

Fig.5 Variation of UCS strength with varying percentage of Lime

\section{CONCLUSIONS:}

The following conclusions were drawn from the test results

- With increase in Bagasse ash content Maximum Dry density decreased due to low specific gravity of bagasse ash and increase in Optimum Moisture content is observed and is due to poor gradation of Bagasse ash.
- Further reduction in Maximum Dry density is seen with addition of Lime to soil Bagasse ash mixture due to decrease in thickness of diffused double layer and increase in in Optimum Moisture content is due to enhancement in water-holding capacity within flocs.

- UCS strength increased with addition of Lime and is attributed due to formation of $\mathrm{CSH}$ and $\mathrm{CASH}$ gels due to pozzolanic reaction. 
- UCS strength is found to be maximum at $15 \%$ Bagasse ash content and hence it is the optimum dosage for the Black cotton soil in the present study.

- UCS strength increased when lime is added up-to $4 \%$ with and without curing and hence $4 \%$ Lime is chosen as the optimum Lime content in the present study.

\section{REFERENCES:}

[1] Martirena, H.J.F., Middendorf, B., Gehrke, M., Budelmann, H., (1998). Use of wastes of the sugar industry as pozzolana in limepozzolana binders: study of the reaction. Cement and Concrete Research 28 (1), pp.1525-1536.

[2] Adrian O. Eberemu, (2013). "Evaluation of bagasse ash treated lateritic soil as a potential barrier material in waste containment application," Acta Geotechnica, Vol.8, pp. 407-421.

[3] Ashish Chhachhia, Anupam Mital (2015). "Review on improvement of clayey soil Stabilized with bagasse ash," IJRREST, Vol.4, No. 1, pp. 238-241.

[4] Ashish Murari, Istuti Singh (2015). "Stabilization of Local Soil with Bagasse Ash,” IJRREST pp.37-39.

[5] Gandhi K.S., (2012) "Expansive soil stabilization using Bagasse Ash" IJERT, Vol. 1 Issue 5.

[6] Chittaranjan, M. Vijay and Keerthi D. (2011) "Agricultural wastes as soil stabilizers" International Journal of Earth Sciences and Engineering, Vol. 04, issue 06 SPL, pp. 50-51

[7] Kharade Amit S., Suryavanshi Vishal V., Gujar Bhikaji S.; Deshmukh Rohankit R.: (2014) "Waste product bagasse ash from sugar industry can be used as stabilizing material for expansive soils" IJRET, ISSN: 2321-7308, March vol.3, issue 3.

[8] Eades, J.L. and R.E. Grim, (1960). Reaction of hydrated lime with pure clay minerals in soil stabilization. Highway Res. Board Bull., 262: 51-53.

[9] Locat, J., H. Trembaly and S. Leroueil, (1996). Mechanical and hydraulic behaviour of a soft inorganic clay treated with lime. Can. Geotech. J., 33(4): 654-669.

[10] Ramesh H.N.,.Krishnaiah A.J. and ShilpaS., (2013). "Effect of Lime on the Index Properties of Black Cotton Soil and Mine tailings mixtures.’IOSR,, Vol.3,No.4. pp.1-7.

[11] Narendra B.S.,Sivapulliah P.V., and Ramesh H.N Adrian O. Eberemu, (2013). "Optimum lime content of fly ash with salt," Ground Improvement (2003) 7, No. 4, pp.187-191

[12] Chen FH (1975), Foundations on expansive soils. Elsevier Scientific Publishing Co., Amsterdam

[13] Justo JL, Saura J, Jaramillo A, Delgado A Gentil P (1985) Prediction and performance for seasonal swelling — shrinkage of buildings on Expansive clays. In: Proceedings of 11th international conf. on Sm and Fe, San Francisco, 4:2199-2204

[14] Day RW (1994) Swell-shrink behavior of compacted clay. J Geotech Eng ASCE 120(3):pp.618-623

[15] Dif AE, Bluemel WF (1991) Expansive soils under cyclic drying and wetting. Geotech Test J ASTM 14(1): pp.96-102

[16] Mir B.A, Sridharan A. Physical and Compaction Behaviour of Clay Soil-Fly Ash Mixtures. Geotech Geol Eng (2013) 31, pp: 10591072

[17] Sivapullaiah, P. V. and Arvind Kumar Jha. (2014). "Gypsum Induced Strength Behaviour of \Fly Ash-Lime Stabilized Expansive Soil", Geotech Geol Eng, Vol.32, pp. 1261-1273.

[18] Adrian O. Eberemu, (2013). "Evaluation of bagasse ash treated lateritic soil as a potential barrier material in waste containment application," Acta Geotechnica, Vol.8, pp. 407-421.

[19] Bell, F.G. (Ed) (1987), Ground Engineers Reference Book, Buttersworth Publication.

[20] Ramesh.H.N, Manoj Krishna.K.V and Mamatha.H.V (2010), "Compaction and Strength Behaviour of Lime treated Black Cotton Soil" Geomechanics and Engineering, Vol.2, No.1, pp 19-28.

[21] Narendra B.S, Sivapullaiah P.V. and RAMES H .N" Optimum lime content of fly ash with salt" Ground Improvement (2003) 7, No. 4,pp. 187-191 